\title{
PENINGKATAN HASIL BELAJAR MATEMATIKA MENGGUNAKAN MODEL PEMBELAJARAN BERBASIS MASALAH PADA PESERTA DIDIK
}

\author{
Aidin Najihi \\ Eka Novianti \\ Universitas MuhammadiyahPalangka raya
}

\begin{abstract}
Abstrak:Penelitian ini bertujuan untuk mengetahui peningkatan hasil belajar peserta didik dalam pembelajaran matematika dengan menggunakan model pembelajaran berbasis masalah.Metode penelitian yang digunakan dalam penelitian ini adalah metode Penelitian Tindakan Kelas (PTK). Penelitian ini menggunakan lembar observasi dan angket. Observasi dilakukan untuk mengamati aktivitas guru, peserta didik, dan pengelolaan pembelajaran..Hasil penelitian menunjukkan bahwa ada peningkatan hasil belajar peserta didik pada saat proses pembelajaran matematika dengan menggunakan model pembelajaran berbaisis masalah pada peserta didik. Hal ini ditunjukan dari data pratindakan sebelum menggunakan model pembelajaran berbasis masalah dimana ketuntasan belajar pra test sebesar 26\%, kemudian pada post test I sebesar 52\% masih belum mencapai 60\%. Maka di lanjutkan pada siklus II dan hasilnya semua peserta didik telah mampu mencapai KKM 6.00, serta ketuntasan belajar post test II sebesar 100\%. Berdasarkan data tersebut maka setelah dilakukan pembelajaran matematika menggunakan model pembelajaran berbasis masalah terjadi peningkatan hasil belajar peserta didik sebesar $74 \%$ dari nilai awal ketuntasan belajar pra test sebesar $26 \%$.
\end{abstract}

Kata Kunci:Model,Pembelajaran Berbasis Masalah, Hasil Belajar, Matematika.

\section{PENDAHULUAN}

Mata pelajaran matematika di sekolah dasar merupakan salah satu program pembelajaran yang bertujuan untuk mempersiapkan peserta didik agar sanggup menghadapi perubahan keadaan didalam kehidupan yang selalu berkembang, melalui latihan bertindak atas dasar pemikiran secara logis, rasional, kritis, cermat, jujur, dan efektif. Selain itu juga membina perubahan dan harapan kehidupan pada anak, juga mempersiapkan peserta didik agar menggunakan matematika dan pola pikir matematika dalam kehidupan sehari-hari, dan dalam mempelajari berbagai ilmu pengetahuan.

Namun sejauh ini mata pelajaran matematika masih saja menjadi sebuah hal yang menarik untuk dibahas, terutama untuk lingkungan sekolah yang berada di daerah terpencil.Masih sering terdengar keluhan tentang kurangnya minat dan motivasi peserta didik dalam mengikuti kegiatan pembelajaran matematika, sehingga mengakibatkan rendahnya hasil belajar matematika peserta didik.

Mata pelajaran matematika seringkali dirasakan sulit dan tidak menarik oleh peserta didik sehingga cenderung tidak disenangi. Akibatnya tidak sedikit peserta didik yang malas untuk mempelajari matematika dan akhirnya mengalami kesulitan belajar matematika, yang berujung pada rendahnya hasil belajar matematika peserta didik.

Sedangkan mata pelajaran matematika sangat perlu di berikan kepada semua peserta didik, mulai dari sekolah dasar seperti yang terdapat dalam 
Lampiran Peraturan Menteri Pendidikan Nasional (Permendiknas) RI No. 22 Tahun 2006, menyebutkan bahwa "mata pelajaran matematika perlu diberikan kepada semua peserta didik mulai dari sekolah dasar untuk membekali peserta didik dengan kemampuan berfikir logis, analitis, sistematis, kritis dan kreatif, serta kemampuan bekerja sama". Menurut hasil penelitian Wulan Fitriyani (2005) menunjukan bahwa "pembelajaran dengan menggunakan model pembelajaran berbasis masalah dapat meningkatkan hasil belajar peserta didik, yang ditandai dengan kepuasan dan kebanggaan yang menumbuhkan motivasi belajar pada peserta didik, serta hasil belajar yang diperoleh secara menyeluruh dan bermakna bagi peserta didik".

Hasil belajar merupakan sebuah kalimat yang terdiri atas dua kata yaitu hasil dan belajar yang memiliki arti yang berbeda.Hasiladalah sesuatu yang didapat atau diperoleh setelah melakukan suatu kegiatan. Sedangkan menurut pendapat Djamarah (2011) menyatakan bahwa “ hasil adalah prestasi dari suatu kegiatan yang telah dikerjakan, diciptakan, baik secara individu maupun kelompok".

Sedangkan pengertian belajar adalah suatu proses atau kegiatan yang dilakukan individu untuk memperoleh kepandaian atau ilmu sehingga terjadi perubahan pada kognitif, apektif dan psikomotoriknya sebagai hasil interaksi terhadap lingkungannya yang relatife tetap.

Hal ini senada dengan pernyataan yang dikemukakan oleh Fontana ( dalam Wulan Fitriyani, 2005:18), bahwa " belajar adalah proses perubahan tingkah laku individu yang relatif tetap sebagai hasil dari pengalaman “. Serta dalam Kamus Besar Bahasa Indonesiasecara etimologis belajar memiliki arti " berusaha memperoleh kepandaian atau ilmu”.

Sedangkan Slameto

mengemukakan bahwa "Belajar ialah suatu proses usaha yang dilakukan seseorang untuk memperoleh suatu perubahan tingkah laku yang baru secara keseluruhan , sebagai hasil pengalamannya sendiri dan interaksi dengan lingkungannya". Sedangkan Oemar Hamalik (2008:27) mengemukakan bahwa "Belajar adalah modifikasi atau memperteguh kelakuan melalui pengalaman". Menurut pengertian ini, belajar merupakan suatu proses, suatu kegiatan dan bukan suatu hasil atau tujuan. Belajar bukan hanya mengingat akan tetapi lebih luas dari itu yakni mengalami. Hasil belajar bukan suatu penguasaan hasil latihan melainkan pengubahan kelakuan.

\section{Menurut Suharsimi Arikunto}

(2011) menyatakan bahwa "hasil belajar adalah hasil akhir setelah mengalami proses belajar, perubahan itu tampak dalam perbuatan yang dapat diamati, dan dapat diukur". Sedangkan menurut Poerwodarminto (1991: 768), hasil belajar adalah hasil yang dicapai (dilakukan, dikerjakan), dalam hal ini hasil belajar merupakan hasil pekerjaan, hasil penciptaan oleh seseorang yang diperoleh dengan ketelitian kerja serta perjuangan yang membutuhkan pikiran.

Matematika sangat diperlukan dalam mengembangkan pengetahuan dasar sebagai bekal menghadapi kehidupan masa depan.Sulis Sutrisna (2005:III) berpendapat bahwa "Matematika adalah ilmu yang berfungsi untuk mengembangkan kemampuan menghitung dan mengukur dengan menggunakan rumus matematika dan turunannya (melalui materi pengukuran dan geometri, aljabar serta trigonometri)".

Mata pelajaran Matematika perlu diberikan kepada semua peserta didik mulai dari sekolah dasar untuk membekali peserta didik dengan kemampuan berpikir logis, analitis, sistematis, kritis, dan kreatif, serta kemampuan bekerjasama. Kompetensi tersebut diperlukan agar peserta didik dapat memiliki kemampuan memperoleh, mengelola, dan memanfaatkan informasi untuk bertahan hidup pada keadaan yang selalu berubah, tidak pasti, dan kompetitif. 
Pemecahan masalah merupakan bagian dari kurikulum matematika yang sangat penting karena dalam proses pembelajaran maupun penyelesaian, siswa dimungkinkan memperoleh pengalaman menggunakan pengetahuan serta keterampilan yang sudah dimiliki untuk diterapkan pada pemecahan masalah yang bersifat tidak rutin.

Pembelajaran matematika

hendaknya dimulai dengan pengenalan masalah atau mengajukan masalah riil atau nyata, yaitu pembelajaran yang mengaitkan dengan kehidupan sehari-hari peserta didik, kemudian peserta didik secara bertahap dibimbing untuk menguasai konsep matematika dengan melibatkan peran aktif peserta didik dalam proses pembelajaran. Hal ini sesuai dengan Lampiran Peraturan Menteri Pendidikan Dasar ( Permendiknas ) RI No.22 Tahun 2006, menyebutkan bahwa dalam setiap kesempatan pembelajaran matematika hendaknya dimulai dengan pengenalan masalah yang sesuai dengan situasi (contextual problem). Lebih lanjut dikemukakan dalam salah satu tujuan mata pelajaran matematika adalah “ memecahkan masalah yang meliputi kemampuan memahami masalah, merancang model matematika, menyelesaikan model dan menafsirkan solusi yang diperoleh “.

Menurut Hudojo (dalam Wulan Fitriyani, 2005), syarat suatu masalah bagi seorang peserta didik adalah pertanyaan yang dihadapkan kepada seorang peserta didik haruslah dapat dimengerti peserta didik tersebut, namun pertanyaan itu harus merupakan tantangan bagi peserta didik untuk menjawabnya dan pertanyaan tersebut tidak dapat dijawab dengan prosedur rutin yang telah diketahui peserta didik.Pembelajaran berbasis masalah dikenal dengan Problem Based Learning (PBL) adalah strategi pembelajaran yang bepusat pada peserta didik dimana peserta didik mengelaborasikan pemecahan masalah dengan pengalaman sehari-hari. Arends (dalam Wardani, 2006:5) mengemukakan bahwa "pembelajaran berbasis masalah merupakan model pembelajaran yang bertujuan merangsang terjadinya proses berfikir tingkat tinggi dalam situasi yang berorientasi masalah".

HS Barrows (dalam Ibrahim, 2002) menyatakan bahwa"proses pembelajaran berbasis masalah adalah suatu model pembelajaran yang didasarkan pada prinsip menggunakan masalah sebagai titik awal akuisisi dan integrasi pengetahuan baru". Sementara itu Satyasa (2008:2) mendefinisikan pembelajaran berbasis masalah sebagai suatu pendekatan pembelajaran dengan membuat konfrontasi kepada peserta didik dengan masalahmasalahpraktis, berbentuk ill-structured, atau open ended melalui stimulus dalam belajar. Sementara itu Moffit ( dalam Supinah, 2008:62) mendifinisikan pembelajaran berbasis masalah, sebagai suatu pendekatan yang melibatkan peserta didik dalam penyelidikan dalam pemecahan masalah yang memadukan keterampilan dan konsep dari berbagai kandungan area.

Berdasarkan pendapat para ahli diatas maka dapat disimpulkan bahwa PBL adalah suatu model pembelajaran yang diawali dengan pemberian suatu masalah yang kontekstual yaitu masalah yang terkait dengan masalah dunia nyata peserta didik. Selanjutnya peserta didik dibimbing untuk menyelesaikan masalah tersebut dengan menerapkan pengetahuan yang telah dimiliki atau diperoleh sebelumnya kedalam situasi baru yang belum dikenalnya (pengetahuan baru).Secara garis besar PBL terdiri dari kegiatan menyajikan kepada peserta didik suatu situasi masalah yang autentik dan bermakna serta memberikankemudahan kepada mereka untuk melakukan penyelidikan dan inkuiri.

\section{METODOLOGI}

Penelitian ini akan dilaksanakan pada bulan Mei sampai dengan bulan Desember 2012, yakni pada tahun pelajaran 2012 / 2013. 
Penelitian ini dilaksanakan pada peserta didik kelas V SD Negeri 1 Sei Puring Kecamatan Antang Kalang dengan subjek seluruh peserta didik kelas V pada semester I yang berjumlah 23 orang peserta didik.Penelitian ini menggunakan rancangan Penelitian Tindakan Kelas ( PTK ) yang didefinisikan sebagai suatu bentuk penelitian yang bersifat reflektif dengan melakukan tindakan-tindakan tertentu untuk memperbaiki dan meningkatkan praktik pembelajaran dikelas secara lebih berkualitas sehingga peserta didik dapat memperoleh hasil belajar yang lebih baik.Penelitian tindakan kelas juga dapat menjembatani kesenjangan antara teori dan praktik pembelajaran.Hal ini terjadi karena setelah menelitikegiatannya sendiri, dikelas sendiri, dengan melibatkan peserta didiknya sendiri, melalui sebuah tindakantindakan yang direncanakan, dilaksanakan, dan dievaluasi sendiri.Sehingga dapat diperoleh umpan balik yang sistematik mengenai kegiatan yang selama ini selalu dilakukan dalam kegiatan belajar mengajar.

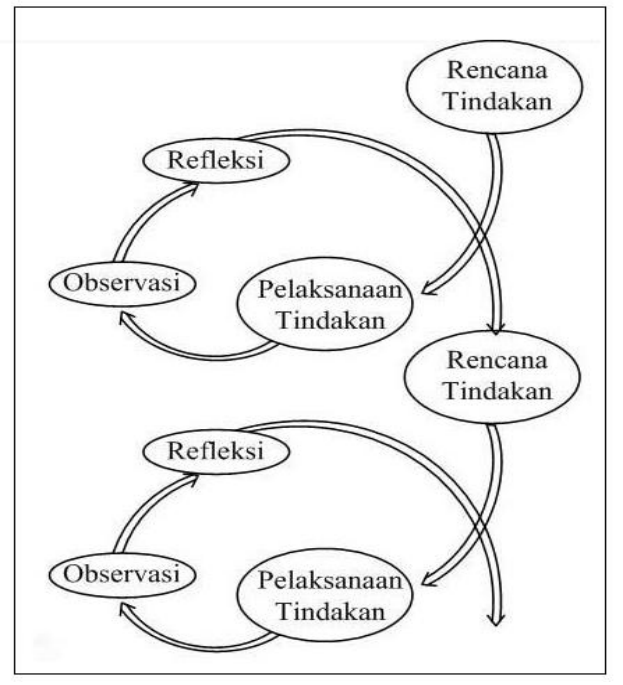

Gambar 1

Model Kemmis \& Taggart

Data yang diperlukan pada penelitian ini diperoleh melalui test tertulis dan observasi. Tes ini bertujuan untuk mengetahui keberhasilan peserta didik selama dalam kegiatan pembelajaran matematika khususnya pada materi operasi Hitung KPK dan FPB menggunakan model pembelajaran berbasis masalah. Hasilnya digunakan sebagai acuan untuk melihat peningkatan hasil belajar peserta didik dalam mengikuti proses pembelajaran, dan untuk menganalisa serta merefleksi kegiatan pembelajaran berikutnya.

\section{HASIL DAN PEMBAHASAN}

Setelah mengikuti proses pembelajaran Matematika dengan menggunakan model pembelajaran berbasis masalah (PBL), menurut pengamatan peneliti pada iklus I dari lima aspek yang dinilai dan diamati pada pembelajaran tersebut masih belum maksimal karena hanya dua aspek yang memperoleh kategori baik. Dengan demikian proses pembelajaran Matematika pada siklus I masih belum efektif dan maksimal.

\begin{tabular}{|c|c|c|c|c|c|c|}
\hline \multirow[t]{2}{*}{ No. } & \multirow{2}{*}{$\begin{array}{c}\text { Aspek } \\
\text { yang } \\
\text { diamati }\end{array}$} & \multicolumn{4}{|c|}{ Kualitas kriteria } & \multirow[t]{2}{*}{ Kateg ori } \\
\hline & & $\begin{array}{l}\mathbf{P} \\
1\end{array}$ & $\mathbf{P}$ & $\mathbf{R}$ & $\mathbf{X R}$ & \\
\hline 1. & $\begin{array}{l}\text { Mengkon } \\
\text { disikan } \\
\text { peserta } \\
\text { didik }\end{array}$ & 3 & 3 & 3 & \multirow{5}{*}{2.5} & \multirow{5}{*}{ Cukup } \\
\hline 2. & $\begin{array}{l}\text { Merenca } \\
\text { nakan } \\
\text { pembelaj } \\
\text { aran }\end{array}$ & 3 & 3 & 3 & & \\
\hline 3. & $\begin{array}{l}\text { Melaksa } \\
\text { nakan } \\
\text { pembelaj } \\
\text { aran }\end{array}$ & 2 & 2 & 2 & & \\
\hline 4. & $\begin{array}{l}\text { Melibatk } \\
\text { an } \\
\text { peserta } \\
\text { didik } \\
\text { dalam } \\
\text { pembelaj } \\
\text { aran }\end{array}$ & 3 & 3 & 3 & & \\
\hline 5. & $\begin{array}{l}\text { Mengori } \\
\text { entasikan } \\
\text { peserta } \\
\text { didik }\end{array}$ & 2 & 2 & 2 & & \\
\hline
\end{tabular}




\begin{tabular}{|c|c|c|c|c|}
\hline & $\begin{array}{l}\text { pada } \\
\text { masalah }\end{array}$ & & & \\
\hline 6. & $\begin{array}{l}\text { Mengorg } \\
\text { anisasika } \\
\text { n peserta } \\
\text { didik } \\
\text { untuk } \\
\text { belajar }\end{array}$ & 3 & 3 & 3 \\
\hline 7. & $\begin{array}{l}\text { Membant } \\
\text { u peserta } \\
\text { didik } \\
\text { dalam } \\
\text { pemecah } \\
\text { an } \\
\text { masalah }\end{array}$ & 2 & 2 & 2 \\
\hline 8. & $\begin{array}{l}\text { Mengana } \\
\text { lisis } \\
\text { proses } \\
\text { pemecah } \\
\text { an } \\
\text { masalah }\end{array}$ & 2 & 2 & 2 \\
\hline 9. & $\begin{array}{l}\text { mengeva } \\
\text { luasi }\end{array}$ & 3 & 3 & 3 \\
\hline
\end{tabular}

Tabel 1. Hasil Pengamatan Akti vitas Guru Siklus 1

\begin{tabular}{|c|c|c|c|c|}
\hline No. & $\begin{array}{c}\text { Nama Pese rta } \\
\text { Didik }\end{array}$ & $\begin{array}{l}\text { Tes Awal } \\
\text { (pra test) }\end{array}$ & $\begin{array}{c}\text { Siklus I } \\
\text { (post test I) }\end{array}$ & $\begin{array}{c}\text { Siklus II } \\
\text { (post test II) }\end{array}$ \\
\hline 1. & Andi & 40 & 50 & 70 \\
\hline 2. & Hendri & 50 & 60 & 70 \\
\hline 3. & Hendro Saputra & 40 & 50 & 70 \\
\hline 4. & Heri Saputra & 50 & 60 & 70 \\
\hline 5. & Irvan Kristian & 40 & 60 & 60 \\
\hline 6. & Jeki & 50 & 50 & 70 \\
\hline 7. & Musim & 60 & 60 & 70 \\
\hline 8. & Saiful & 40 & 50 & 70 \\
\hline 9. & Yogi Susilo & 60 & 70 & 90 \\
\hline 10. & Desi & 40 & 60 & 70 \\
\hline 11. & Devi & 30 & 50 & 60 \\
\hline 12. & HeniPertiwi & 60 & 60 & 70 \\
\hline 13. & Lassamini & 40 & 50 & 70 \\
\hline 14. & Liya & 30 & 50 & 60 \\
\hline 15. & Pira & 50 & 60 & 70 \\
\hline 16. & Remy & 40 & 50 & 60 \\
\hline 17. & Rentika Apriliya & 60 & 60 & 80 \\
\hline 18. & Rusni & 30 & 50 & 70 \\
\hline 19. & Santi & 40 & 50 & 70 \\
\hline 20. & Wira & 60 & 70 & 80 \\
\hline 21. & Weni Rahayu & 50 & 70 & 70 \\
\hline 22. & Yuni & 30 & 50 & 60 \\
\hline 23. & Yunita & 70 & 80 & 100 \\
\hline & Jumlah & 1.060 & 1.320 & 1.630 \\
\hline & Rata-rata & 46,08 & 57,39 & 70,86 \\
\hline
\end{tabular}

Jadi dapat disimpulkan bahwa dalam proses pembelajaran Matematika dengan menggunakan model pembelajaran berbasis masalah pada siklus I masih belum mencapai kategori baik dan belum mampu mencapai KKM 6.00, serta ketuntasan belajar tidak mencapai $60 \%$. Sehingga peneliti melakukan kegiatan pembelajaran kembali yaitu pada siklus II, agar pembelajaran Matematika lebih efektif dan maksimal serta dapat mencapai KKM 6.00 dengan memperhatikan hasil observasi yang ada sebagai dasar tindakan selanjutnya.

Kegiatan Siklus II dilaksanakan setelah kegiatan siklus I dengan berpedoman dengan hasil refleksi yang dilakukan terhadap pelaksanaan siklus I tersebut. Dengan kata lain siklus II merupakan penyempurnaan dari siklus I. Data siklus II terdiri atas (1) data situasi belajar mengajar, (2) data hasil belajar, (3) data refleksi.

Tabel 2. Hasil Siklus 1 dan Siklus II

Berdasarkan tabel hasil belajar diatas terlihat dengan jelas adanya peningkatan pada rata-rata kelas dari tes pratindakan, siklus I sampai pada siklus II. Hal ini menunjukan bahwa dengan menerapkan model pembelajaran berbasis masalah sangat baik, karena pada post test II memperoleh nilai yang sangat baik mampu mencapai KKM 6.00 dan ketuntasan belajar mencapai lebih dari $60 \%$ yaitu $100 \%$.

Berdasarkan hasil observasi yang dilakukan pada tahap awal, dapat diketahui bahwa penyebab tidak maksimalnya pembelajaran dan rendahnya hasil belajar karena faktor peserta didik dan guru.Peserta didik menunjukan sikap negative terhadap pembelajaran matematika, hal ini terlihat dari peserta didik yang kebanyakan tidak fokus dalam mengikuti kegiatan pemebalajaran serta 
kurangnya pemahaman konsep peserta didik terhadap matematika terutama operasi hitung KPK dan FPB.Selanjutnya guru cenderung kurang memperhatikan strategi dan model pembelajaran yang sesuai digunakan pada materi pelajaran.

Hasil nilai awal yang telah ada menunjukan bahwa kemampuan peserta didik dalam pembelajaran matematika masih rendah karena ketuntasan belajar peserta didik kurang dari $60 \%$ yaitu hanya $26 \%$ saja dan belum mampu mencapai KKM 6.00. Hasil belajar tersebut membuktikan bahwa kemampuan peserta didik masih sangat kurang dalam pembelajaran matematika. Sedangkan keberhasilan dan ketuntasan belajar dalam penelitian ini adalah peserta didik mampu mencapai KKM 6.00 dan ketuntasan belajar mencapai $60 \%$ keatas.

Hasil dari penerapan model pembelajaran berbasis masalah pada pembelajaran matematika siklus I masih belum menunjukan hasil yang maksimal, karena hasil belajar yang diperoleh masih belum mampu menacapai KKM 6.00 dan ketuntasan belajar hanya mencapai $52 \%$ dan belum mencapai kriteria ketuntasan 60\%. Maka diambil kesimpulan bahwa penelitian tindakan pada siklus I masih belum berhasil.Sehingga dilakukan kembali penelitian tindakan yaitu siklus II sebagai tindak lanjut dari penelitian pada siklus I.

Pada siklus II pembelajaran matematika dengan menggunakan model pembelajaran berbasis masalah sudah terlaksana dengan baik mengalami peningakatan yang sangat baik. Berdasarkan data hasil belajar peserta didik pada siklus II juga mengalami peningkatan yaitu ketuntasan belajar diatas $60 \%$ yaitu $100 \%$ dan semua peserta didik telah mampu menacapai KKM yaitu 5 orang atau $22 \%$ peserta didik mendapat nilai 60,14 orang atau $61 \%$ peserta didik mendapat nilai 70,2 orang atau $9 \%$ peserta didik mendapat nilai 80, 1 orang atau $4 \%$ peserta didik mendapat nilai 90 dan 1 Orang atau $4 \%$ peserta didik yang mendapat nilai 100 . Dilihat secara keseluruhan bahwa respon peserta didik terhadap pembelajaran matematika dengan menggunakan model pembelajaran berbasis masalah dapat dikategorikan baik, hal ini menunjukan bahwa aktivitas pembelajaran yang terlihat pada saat proses pembelajaran berlangsung dan hasil belajar peserta didik pada siklus II menunjukan peningkatan dibandingkan pada data awal pratindakan dan data siklus I.

Berdasarkan hasil penelitian tersebut dapat diambil kesimpulan bahwa penelitian tindakan kelas sangat efektif bila di terapkan untuk meningktakan hasil belajar peserta didik asalkan disesuaikan dengan materi dan karakteristik peserta didik.

\section{KESIMPULAN}

Berdasarkan hasil analisis data penelitian, maka dapat disimpulkan bahwa penggunaan model pembelajaran berbasis masalah pada mata pelajaran matematika dapat meningkatkan hasil belajar peserta didik kelas V SDN 1 Sei Puring Tahun Pelajaran 2012/2013 pada semester ganjil. Hal ini ditunjukan dari data pratindakan sebelum menggunakan model pembelajaran berbasis masalah dimana ketuntasan belajar pra test sebesar $26 \%$, kemudian pada post test I sebesar $52 \%$ masih belum mencapai 60\%. Maka di lanjutkan pada siklus II dan hasilnya semua peserta didik telah mampu mencapai KKM 6.00, serta ketuntasan belajar post test II sebesar $100 \%$. Berdasarkan data tersebut maka setelah dilakukan pembelajaran matematika menggunakan model pembelajaran berbasis masalah terjadi peningkatan hasil belajar peserta didik sebesar $74 \%$ dari nilai awal ketuntasan belajar pra test sebesar $26 \%$.

\section{DAFTAR PUSTAKA}

Djamarah, (2011). Pengertian Belajar dan Hasil 
Belajar.http://Duniabaca.com.html. Diakses tanggal 03 Maret 2012

Fajar Shadiq, (2003).Penalaran,

Pemecahan Masalah dan

Komunikasi dalam Pembelajaran

Matematika. Yogyakarta: PPPG

Matematika

Herman Hudojo, (2003).Pengembangan

Kurikulum dan Pembelajaran

Matematika. Malang: Jurusan

Matematika FMIPA UNM

Heruman, (2007). Model Pembelajaran

Matematika di Sekolah Dasar.

Bandung: PT Remaja Rosdakarya

Hollands, (1991).Kamus Matematika.

Jakarta: Penerbit Erlangga

Koesmartono, \& Rawuh,

(2001).Matematika Pendahuluan.

Bandung: ITB

Kunandar, (2010).Langkah Mudah

Peneltian Tindakan Kelas Sebagai

Pengembangan Profesi Guru.

Jakarta: PT RajaGrafindo Persada

Margono, (2009).Metodologi Penelitian

Pendidikan. Jakarta: PT Rineka

Cipta

Mohammad Asrori, (2008).Penelitian

Tindakan Kelas. Bandung: CV

Wacana Prima

Mustofa Usman, dkk, (2009).Statistik.

Bandung: PT Sinar Baru Algesindo

Riduwan, (2009). Metode dan Teknik

Menyusun Proposal Penelitian.

Bandung: Alfabeta

Sugiyono, (2007).Statistik untuk

Penelitian. Bandung: PT Alfabeta

Suharsimi Arikunto, (2006).Prosedur

Penelitian. Jakarta: PT Rineka Cipta
Suharsimi Arikunto, dkk, (2009).Penelitian Tindakan

Kelas.Jakarta: PT Bumi Aksara

Suharsimi Arikunto, (2011). Pengertian Belajar dan Hasil Belajar.

http://Dunia baca.com.html. Diakses

03 Maret 2012

Sulis Sutrisna, (2005). Aku Ingin Menjadi

Ahli Matematika. Depok: Kawan

Pustaka

Sumardiyono, (2007).Tips dalam

Penerapan Pembelajaran Problem

Solving. Yogyakarta: PPPPTK

Matematika

Supinah, (2008).Pengaruh Strategi

Pembelajaran dan Gaya Berfikir

Terhadap Hasil Belajar Matematika

Siswa Eksperimen pada Siswa SMP

di daerah Istimewa

Yogyakarta.Yogyakarta: Laporan

Desertasi

Supinah, \& Titik Sutanti, (2010).Pembelajaran Berbasis Masalah di SD. Yogyakarta: PPPPTK Matematika

Tim, (2008).Buku Pedoman Penulisan Skripsi. Palangkaraya: Universitas

Muhammadiyah Palangkaraya

Wulan Fitriyani, (2005).Upaya Meningkatkan Hasil Belajar

Pecahan Siswa Kelas IV SD

Sekaran 01 Kota Semarang Tahun

Pelajaran 2004/2005 Melalui

Pembelajaran Berbasis Masalah.

Semarang: Universitas Negeri

Semarang 